\title{
SINTESIS NANOPARTIKEL ZnO DAN IMMOBILISASINYA PADA KAIN KAPAS SEBAGAI ABSORBER ULTRAVIOLET
}

\section{SYNTHESIS OF ZnO NANOPARTICLES AND ITS IMMOBILIZATION ON COTTON FABRIC AS ULTRAVIOLET ABSORBER}

\author{
Doni Sugiyana, Wulan Septiani, Agus Surya Mulyawan, Tatang Wahyudi \\ Balai Besar Tekstil, Jalan Jenderal Ahmad Yani No. 390 Bandung \\ E-mail: texirdti@bdg.centrin.net.id
}

Tanggal diterima: 11 Desember 2017, direvisi: 10 Januari 2018, disetujui terbit: 11 Januari 2018

\begin{abstract}
ABSTRAK
Nanopartikel ZnO merupakan salah satu material anorganik yang memiliki sifat absorpsi ultraviolet/UV dan dapat diaplikasikan pada material tekstil untuk memperoleh kemampuan proteksi UV. Dalam penelitian ini dipelajari sintesis nanopartikel $\mathrm{ZnO}$ dan immobilisasinya pada kain kapas sebagai absorber UV. Metodologi penelitian meliputi sintesis suspensi nanopartikel $\mathrm{ZnO}$ dan immobilisasi nanopartikel pada kain kapas dengan metode pad-dry-cure menggunakan agen kationisasi trietilamina (TEA). Evaluasi dilakukan terhadap morfologi nanopartikel yang terimmobilisasi pada permukaan kain, ketahanan perlekatan nanopartikel pada kain dan uji kekuatan tarik pada kain setelah irradiasi UV. Hasil scanning electron microscopy/SEM menunjukkan nanopartikel $\mathrm{ZnO}$ terbentuk dan terimmobilisasi pada permukaan kain dengan ukuran partikel antara 100-500 nm. Nanopartikel ZnO yang terkationisasi dengan TEA 5\% memperlihatkan perlekatan yang baik pada kain kapas setelah melalui uji siram hujan. Setelah irradiasi UV selama 10 jam, penurunan kekuatan tarik pada sampel kain dengan nanopartikel $\mathrm{ZnO}$ pada arah lusi dan pakan masing-masing sebesar 10,6\% dan 9,5\%, lebih rendah dibandingkan sampel kain tanpa nanopartikel $\mathrm{ZnO}$ dengan penurunan kekuatan tarik masing-masing sebesar 23,6\% dan 22,6\% pada arah lusi dan pakan.
\end{abstract}

Kata kunci: kationisasi, kain kapas, nanopartikel ZnO, absorption, ultraviolet.

\section{ABSTRACT}

$\mathrm{ZnO}$ nanoparticle is one of inorganic materials which have ultraviolet/UV absorption property and possibly applied on textile material to obtain UV protection performance. Synthesis of $\mathrm{ZnO}$ nanoparticles and its immobilization onto cotton fabric as UV absorber was studied in this research. Research methods including synthesis of $\mathrm{ZnO}$ nanoparticles suspension, and immobilization of nanoparticles onto cotton fabric applying paddry-cure method cationization of cotton fabric using triethylamine (TEA) as cationizing agent. Evaluations have been done upon immobilized nanoparticles morphology on fabric surface, durability of nanoparticles attachment on fabric and tensile strength testing to the fabric after UV irradiation. Scanning electron microscopy/SEM result shows that $\mathrm{ZnO}$ nanoparticles formed and immobilized on fabric surface with particle size ranging in 100-500 nm. Nanoparticle which has cationized with TEA 5\% shows good attachment on cotton fabric after passing rain shower test. After 10 hrs of UV irradiation, reduction of tensile strength in fabric containing ZnO nanoparticles for warp and weft directions were found $10.6 \%$ and $9.5 \%$ respectively, lower than that of fabric without ZnO nanoparticles with $23.6 \%$ and $22.6 \%$ of respective reduction in warp and weft directions.

Keywords: cationization, cotton fabric, ZnO nanoparticle, absorption, ultraviolet.

\section{PENDAHULUAN}

Pengembangan tekstil fungsional di Indonesia saat ini tengah menjadi topik penelitian yang cukup intensif, baik untuk aplikasi sandang maupun non-sandang. Salah satu jenis tekstil fungsional yang saat ini banyak dikembangkan diantaranya adalah tekstil anti ultraviolet (UV). Aplikasi tekstil anti UV dapat berkembang luas dalam berbagai bidang antara lain : medis, otomotif, konstruksi sipil/arsitektur, functional apparel dan sebagainya, sehingga menjadi topik penelitian yang sangat potensial. Radiasi sinar UV dapat menyebabkan berbagai efek negatif berupa kerusakan/dekomposisi pada material dan kesehatan kulit manusia, apabila tidak dilindungi. ${ }^{1}$ Peningkatan efek rumah kaca dan fenomena 
penipisan lapisan ozon yang semakin intensif menyebabkan jumlah total radiasi UV yang mencapai permukaan bumi meningkat tahun demi tahun. ${ }^{2,3}$ Proteksi kesehatan dan material terhadap efek negatif UV merupakan alasan utama perlunya penelitian yang lebih intensif terhadap tekstil anti UV.

Secara spesifik saat ini tekstil non-sandang anti UV saat ini banyak digunakan sebagai bahan eksterior bangunan (atap tenda), bahan interior otomotif, dan bahan interior ruangan (gorden, vertical blind). Material tekstil dapat berfungsi untuk memproteksi radiasi UV karena adanya kandungan bahan aktif dengan karakteristik daya serap (absorpsi) UV yang optimum dengan metode immobilisasi yang sesuai pada permukaan tekstil. Absorber UV dapat berupa senyawa organik atau anorganik tak berwarna dengan daya absorpsi yang kuat pada rentang panjang gelombang UV 290 $360 \mathrm{~nm}^{4}{ }^{4}$ Dibandingkan absorber UV organik, absorber UV anorganik lebih banyak digunakan dengan beberapa kelebihan antara lain: tahan sinar dan stabilitas yang baik, serta efek proteksi UV yang jauh lebih lama., ${ }^{5,6} \mathrm{TiO}_{2}, \mathrm{CeO}_{2}$ dan $\mathrm{ZnO}$ adalah absorber yang paling banyak digunakan dalam studi proteksi radiasi UV., ${ }^{7,8}$ Dalam perkembangannya, penggunaan partikel berukuran nano sebagai absorber UV merupakan salah satu upaya untuk meningkatkan sifat proteksi UV.

Immobilisasi absorber UV pada beberapa jenis kain dalam berbagai studi dilakukan melalui beberapa metode antara lain: melt-spinning, coating, padding dan lainnya., ${ }^{9,10,11}$ Dalam penelitian penulis sebelumnya, absorber UV nanopartikel $\mathrm{ZnO}$ diimmobilisasikan pada kain kapas untuk atap dengan bantuan binder. ${ }^{12}$ Pengembangan tekstil anti-UV masih memerlukan penelitian lanjutan untuk memperbaiki beberapa aspek seperti: kemampuan proteksi anti-UV, sifat/properti bahan yang lebih baik dan fleksibilitas dalam aplikasinya. Dalam penelitian ini dipelajari sintesis nanopartikel $\mathrm{ZnO}$ dan immobilisasinya pada kain kapas dengan menggunakan agen kationisasi untuk memperoleh tekstil fungsional eksterior dengan kemampuan proteksi UV.

\section{METODE}

\section{Bahan dan peralatan penelitian}

Bahan yang digunakan dalam penelitian ini antara lain: kain tenun kapas gramasi $300 \mathrm{gr} / \mathrm{m}^{2}$ (Kanvas Mulia), seng asetat dihidrat/ZnAc. $2 \mathrm{H}_{2} \mathrm{O}$ (Merck), lithium hidroksida (Merck), trietilamina (Merck), asam asetat (Merck), isopropanol teknis (Brataco), asam klorida pekat (Merck), zat pembasah teepol (Brataco), dan air demineralisasi (Brataco). Peralatan yang digunakan antara lain: mesin pad-dry-cure (Werner Mathis AG), magnetic stirrer, sonikator, oven, dan buret tetes.

\section{Sintesis nanopartikel ZnO}

Sintesis nanopartikel ZnO dilakukan dengan mengikuti metode yang digunakan oleh El-Hady, 2013. ${ }^{13}$ Suspensi nanopartikel $\mathrm{ZnO}$ 0,5\% dibuat dengan mensuspensikan 2.8 gram seng asetat dalam $100 \mathrm{ml}$ isopropanol dengan pemanasan refluks selama 3 jam dalam labu distilasi. Dalam gelas beker lainnya, 0,75 gram lithium hidroksida dilarutkan dalam $100 \mathrm{ml}$ isopropanol pada temperatur kamar dengan menggunakan magnetic stirrer. Suspensi seng asetat didinginkan hingga $0^{\circ} \mathrm{C}$, kemudian larutan lithium hidroksida dimasukkan tetes demi tetes ke dalam suspensi seng asetat di bawah pengadukan cepat. Campuran disonikasi pada temperatur kamar selama 2 jam.

\section{Immobilisasi nanopartikel ZnO pada kain}

Sampel kain terlebih dahulu dipreparasi dengan proses pemasakan (scouring) Proses pemasakan dilakukan dengan mereaksikan sampel kain dalam larutan $\mathrm{Na}_{2} \mathrm{CO}_{3}$, zat pembasah dan air demineralisasi sebanyak 5 liter. Temperatur dinaikkan hingga $90^{\circ} \mathrm{C}$ dan dibiarkan konstan selama 60 menit kemudian diturunkan kembali hingga mencapai temperatur ruang. Sampel kain kemudian dipisahkan dan dicuci dengan air hangat $\left(60^{\circ} \mathrm{C}\right)$, selanjutnya dicuci dengan air dingin $\left(20^{\circ} \mathrm{C}\right)$ hingga $\mathrm{pH}$ air bilasan netral. Sampel kemudian dikeringkan pada temperatur kamar.

Sampel kain yang telah melalui proses pemasakan direndam pada larutan TEA (5\% dan $10 \% \mathrm{v} / \mathrm{v})$ selama 60 menit kemudian diperas (padding) hingga wpu (wet pick-up) 800\%. Sampel kain kemudian dimasukkan ke dalam larutan suspensi nanopartikel $\mathrm{ZnO}$ dan diperas hingga wpu $80 \%$, proses padding pada larutan nanopartikel diulang sebanyak 3 kali. Kain yang telah dipadding dikeringkan (drying) pada temperatur $100^{\circ} \mathrm{C}$ selama 5 menit dan dilanjutkan dengan proses curing pada temperatur $130^{\circ} \mathrm{C}$ selama 3 menit. Kain yang telah melalui proses pad-dry-cure dibiarkan pada temperatur ruang selama 2 jam, kemudian disonikasi selama 30 menit untuk melepaskan nanopartikel $\mathrm{ZnO}$ yang tidak melekat sempurna pada permukaan kain.

\section{Pengujian dan karakterisasi}

Evaluasi karakteristik dan morfologi kain tenun kapas anti UV menggunakan instrumen scanning electron microscopy/SEM (JEOL, JSM 6510). Evaluasi terhadap perubahan perlekatan nanopartikel $\mathrm{ZnO}$ pada kain akibat pengaruh eksternal hujan dievaluasi dengan uji siram air hujan Bundesmann, mengikuti standar SNI ISO 9865:2013. Pengaruh radiasi UV terhadap perubahan sifat fisik kain dievaluasi melalui percobaan irradiasi sinar UV menggunakan fotoreaktor berpenutup yang dilengkapi lampu UVC 3 x 15 watt (Vilbert Lourmat) dengan panjang 
gelombang $254 \mathrm{~nm}$. Perubahan sifat fisik kain dievaluasi melalui pengujian kekuatan tarik (standar SNI 0276:2009).

\section{HASIL DAN PEMBAHASAN}

Karakterisasi nanopartikel terimmobilisasi pada kain

Citra SEM dari sampel kain kapas terimmobilisasi nanopartikel $\mathrm{ZnO}$ yang diperoleh dari proses sintesis dengan bantuan agen kationisasi TEA 0\%; 5\%; dan 10\% ditunjukkan pada Gambar 1. Hasil citra SEM menunjukkan bahwa sintesis yang dilakukan berhasil membentuk nanopartikel $\mathrm{ZnO}$ dan terimmobilisasi pada permukaan kain dengan bantuan proses kationisasi partikel menggunakan TEA. Tanpa penggunaan TEA, nanopartikel yang melekat pada permukaan kain hampir tidak terlihat (Gambar 1-a). Proses immobilisasi nanopartikel $\mathrm{ZnO}$ setelah melalui penambahan TEA (5\% dan 10\%) berhasil menghasilkan perlekatan yang baik pada permukaan kain (Gambar 1-b dan 1-c). Pada pembesaran 10.000x (Gambar 1-d) tampak bahwa nanopartikel menempel dengan cukup erat pada permukaan serat dengan estimasi ukuran nanopartikel antara 100-500 nm.

Meskipun citra SEM pada Gambar 1-d memperlihatkan kecenderungan terjadinya aglomerasi nanopartikel $\mathrm{ZnO}$ pada beberapa bagian permukaan serat, namun secara keseluruhan distribusi/sebaran nanopartikel tampak cukup merata. Penggunaan TEA dengan konsentrasi yang berbeda (5\% dan 10\%) tampak tidak terlalu signifikan dalam menambah sebaran nanopartikel, namun diperkirakan akan mempengaruhi kekuatan perlekatan pada permukaan kain. Dalam studi ini, proses sonikasi setelah immobilisasi nanopartikel $\mathrm{ZnO}$ pada kain secara teoritis mengindikasikan ketahanan perlekatan yang cukup baik, konfirmasi ketahanan perlekatan lebih lanjut dilakukan melalui uji siram hujan yang akan dibahas selanjutnya.

Spektra FTIR kain kapas blanko dan kain kapas terimmobilisasi nanopartikel $\mathrm{ZnO}$ dengan kationisasi menggunakan TEA ditampilkan pada Gambar 2. Hasil analisis spektra FTIR kain kapas menunjukkan adanya penyerapan yang kuat pada bilangan gelombang $2900 \mathrm{~cm}^{-1}$ dan $3383 \mathrm{~cm}^{-1}$ yang merupakan gugus $\mathrm{OH}$ bending dan $\mathrm{OH}$ stretching. Serapan pada $1000 \mathrm{~cm}^{-1}-1250 \mathrm{~cm}^{-1}$ menunjukkan hadirnya gugus $\mathrm{C}-\mathrm{O}$ dan $\mathrm{C}-\mathrm{O}-\mathrm{C}$. Puncak pada bilangan gelombang $1620 \mathrm{~cm}^{-1}-1649 \mathrm{~cm}^{-1}$ berkaitan dengan hadirnya cincin aromatik dan peregangan ikatan $\mathrm{C}-\mathrm{H}$ dan $\mathrm{OH}$. Pada kurva spektra kain kapas terimmobilisasi nanopartikel $\mathrm{ZnO}$, terdapat serapan yang kuat pada bilangan gelombang $1568 \mathrm{~cm}^{-1}$ menunjukkan keberadaan gugus $\mathrm{NH}_{2}$, yang tidak terdapat pada blanko sampel kain. Keberadaan gugus amina tersebut mengindikasikan terjadinya ikatan antara $\mathrm{N}-\mathrm{ZnO}$ dengan serat kain kapas.
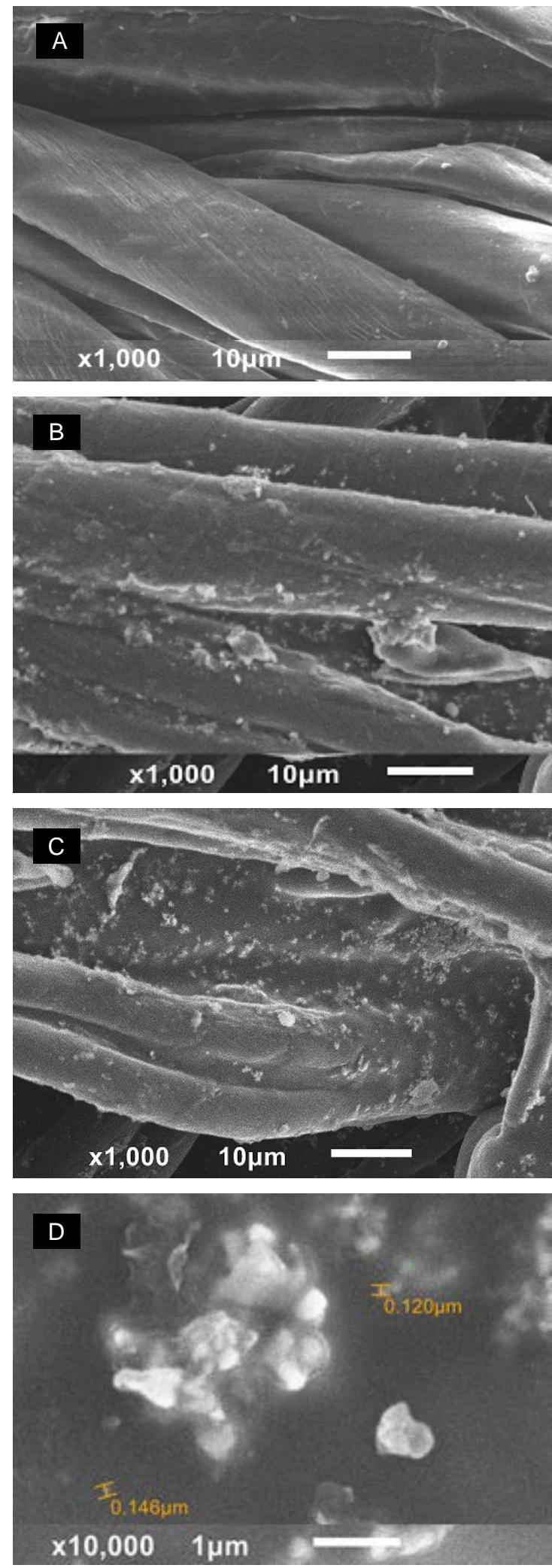

Gambar 1.Citra SEM kain terimmobilisasi nanopartikel ZnO: A) TEA 0\% (1000x); B) TEA 5\% (1000x); C) TEA $10 \%$ (1000x); D) TEA 10\% (10.000x). 


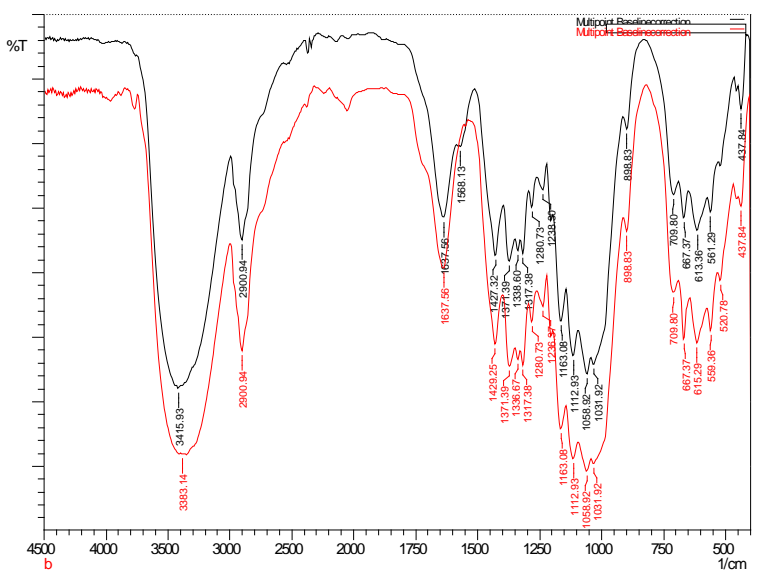

Gambar 2. Hasil uji FTIR kain terimmobilisasi nanopartikel TEA 5\%.

(A)

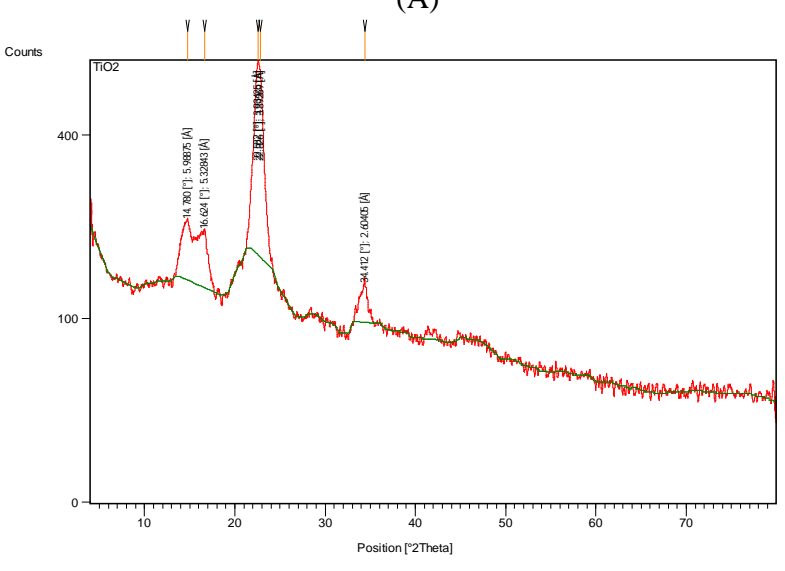

(B)

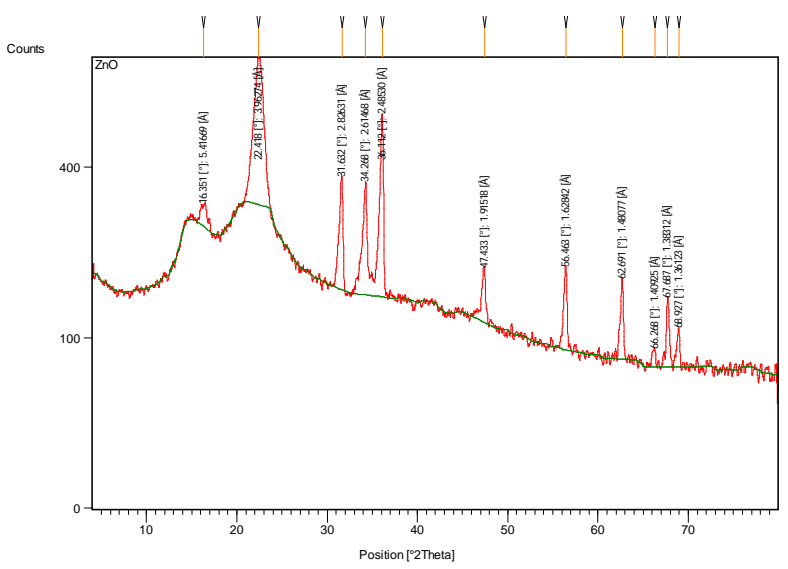

Gambar 3. Hasil uji XRD: A) kain blanko; B) kain terimmobilisasi nanopartikel $\mathrm{ZnO}$ $5 \%$.
Hasil uji XRD terhadap sampel kain kapas sebelum dan setelah immobilisasi nanopartikel ZnO dari proses sintesis dengan konsentrasi TEA 5\% ditunjukkan pada Gambar 3. Dibandingkan dengan grafik uji XRD sampel blanko (sebelum immobilisasi absorber UV), maka grafik uji XRD pada sampel setelah immobilisasi nanopartikel $\mathrm{ZnO}$ menunjukkan adanya puncak di sekitar sudut $2 \theta$ : 31,63; 34,27; 36,11; 47,43; 56,46; 62,69 dan 67,69 . Berdasarkan tabel referensi uji XRD, puncak tersebut dapat diinterpretasikan sebagai keberadaan senyawa oksida $\mathrm{ZnO}$ dengan fase kristal heksagonal.

\section{Ketahanan perlekatan nanopartikel ZnO pada kain}

Ketahanan perlekatan nanopartikel $\mathrm{ZnO}$ pada sampel kain dievaluasi melalui uji siram hujan. Dalam aplikasinya, tekstil fungsional yang menjadi objek dalam penelitian ditujukan untuk penggunaan eksterior seperti tenda atap, sehingga diperkirakan akan terkena pengaruh cuaca seperti hujan. Ketahanan (durability) perlekatan nanopartikel ZnO pada sampel kain terkationisasi TEA 5\% dievaluasi melalui uji siram air hujan selama 10 menit dan 60 menit. Gambar 4 memperlihatkan citra SEM permukaan sampel kain terimmobilisasi nanopartikel $\mathrm{ZnO}$ setelah uji siram hujan. Hasil percobaan menunjukkan bahwa nanopartikel $\mathrm{ZnO}$ masih tampak melekat dengan baik pada uji siram hujan 10 menit maupun 60 menit.

Perlekatan nanopartikel ZnO pada kain kapas dimungkinkan oleh perubahan muatan $\mathrm{ZnO}$ melalui proses kationisasi oleh TEA, sehingga menghasilkan senyawa $\mathrm{N}-\mathrm{ZnO}$ yang bermuatan positif, yang selanjutnya berikatan dengan gugus hidroksil pada selulosa. Pada studi oleh Wu, 2012, mekanisme ini juga dipelajari pada perlekatan N$\mathrm{TiO}_{2}$ pada kain kapas dengan bantuan TEA, dengan hasil perlekatan cukup baik. $^{14}$ Penggunaan konsentrasi TEA 5\% cukup efektif dalam mempertahankan ikatan antara nanopartikel $\mathrm{ZnO}$ dan serat pada kain kapas. Pada konsentrasi TEA yang lebih tinggi (10\%) diperkirakan akan menimbulkan ikatan yang lebih baik setelah uji siram hujan, namun tidak dievaluasi lebih lanjut dalam studi ini. Ketahanan perlekatan setelah uji siram akan dikonfirmasi lebih lanjut melalui evaluasi performa absorpsi UV sampel kain sebelum dan setelah uji siram hujan, yang direpresentasikan sebagai ketahanan sifat kekuatan tarik kain terhadap radiasi UV.

\section{Evaluasi performa absorpsi UV oleh kain}

Kemampuan kain dalam mengabsorpsi radiasi UV akan memproteksi perubahan sifat fisik kain seperti kekuatan tariknya. Pengaruh immobilisasi nanopartikel $\mathrm{ZnO}$ sebagai absorber UV pada sampel kain kapas terhadap perubahan 
sifat kekuatan tarik dipelajari melalui evaluasi perubahan kekuatan tarik kain selama proses irradiasi UV. Pemaparan radiasi sinar UV dilakukan pada kain blanko (tanpa nanopartikel $\mathrm{ZnO}$ ) dan sampel kain terimmobilisasi nanopartikel $\mathrm{ZnO}$ dengan konsentrasi agen kationisasi (TEA) 5\%. Percobaan juga bertujuan untuk mengevaluasi ketahanan perlekatan nanopartikel $\mathrm{ZnO}$ setelah uji siram. Percobaan irradiasi UV dilakukan dengan fungsi waktu pemaparan hingga 10 jam. Hasil uji kekuatan tarik pada sampel kain ditunjukkan pada Gambar 5.
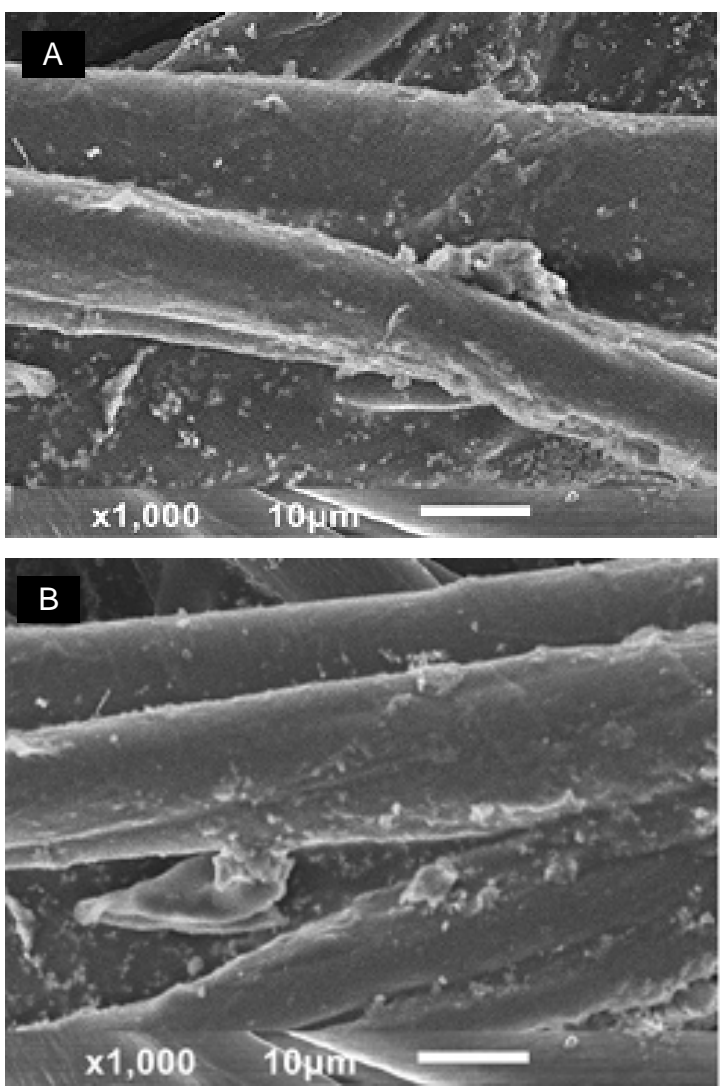

Gambar 4. Citra SEM kain terimmobilisasi nanopartikel ZnO: A) setelah uji siram 10 menit; B) setelah uji siram hujan 60 menit. (TEA 5\%)

Hasil uji kekuatan tarik (Gambar 5) memperlihatkan adanya penurunan kekuatan tarik sampel kain kapas arah lusi dan pakan seiring peningkatan waktu irradiasi UV. Setelah pemaparan radiasi UV selama 10 jam, kain blanko mengalami penurunan kekuatan tarik pada arah lusi dan pakan masing-masing sebesar 23,6\% dan 22,6\%. Sementara, kain terimmobilisasi nanopartikel $\mathrm{ZnO}$ sebelum uji siram hujan mengalami penurunan kekuatan tarik pada arah lusi dan pakan masingmasing sebesar 10,6\% dan 9,5\%. Kain terimmobilisasi nanopartikel $\mathrm{ZnO}$ setelah uji siram hujan selama 10 menit mengalami penurunan kekuatan tarik pada arah lusi dan pakan masingmasing sebesar 10,8\% dan 10,2\%. Lebih jauh, penambahan durasi uji siram hujan hingga 60 menit menyebabkan kain terimmobilisasi nanopartikel $\mathrm{ZnO}$ mengalami penurunan kekuatan tarik pada arah lusi dan pakan masing-masing sebesar $11,0 \%$ dan $10,3 \%$.

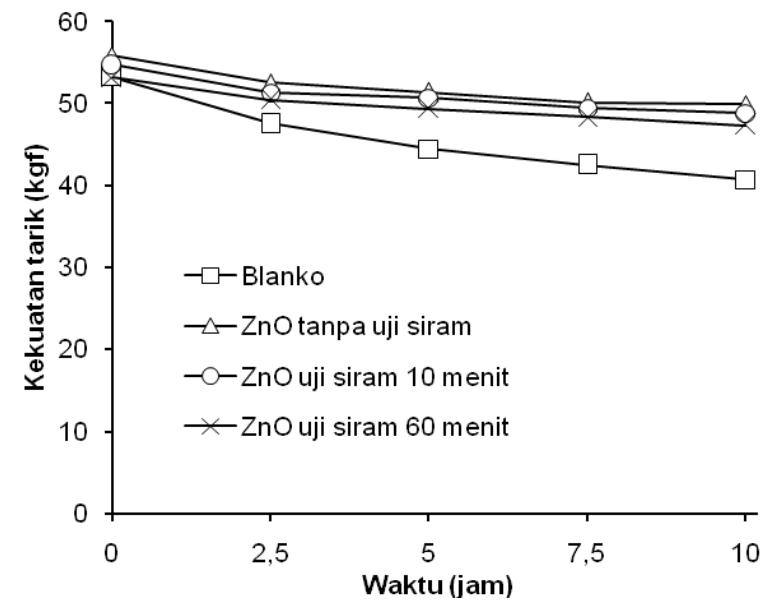

(B)

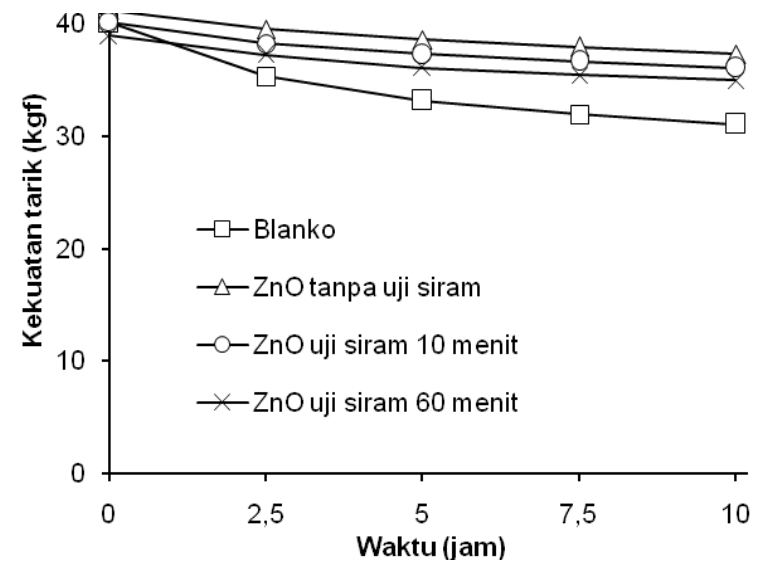

Gambar 5. Grafik uji kekuatan tarik kain: A) arah lusi; B) arah pakan.

Berdasarkan hasil percobaan pada Gambar 5, tampak bahwa immobilisasi nanopartikel $\mathrm{ZnO}$ terkationisasi pada kain kapas mampu menghambat penurunan kekuatan tarik kain pada arah lusi dan pakan lebih dari 50\%, dibandingkan sampel kain blanko. Sampel kain terimmobilisasi nanopartikel $\mathrm{ZnO}$ setelah proses uji siram hujan selama 10 menit dan 60 menit, tidak mengalami penurunan performa absorpsi UV yang signifikan dibandingkan dengan sampel kain terimmobilisasi nanopartikel $\mathrm{ZnO}$ sebelum uji siram hujan. Hal ini mengindikasikan 
dua hal yaitu nanopartikel ZnO mampu bekerja dengan baik sebagai absorber UV dan immobilisasi partikel yang cukup baik

Pada penelitian penulis sebelumnya, immobilisasi nanopartikel $\mathrm{ZnO}$ pada kain kapas dengan menggunakan binder akrilat, dicapai penurunan kekuatan tarik pada arah lusi dan pakan masing-masing sebesar $1,4 \%$ dan $1,7 \%$ setelah irradiasi UV selama 5 jam. ${ }^{12}$ Dalam studi tersebut, digunakan nanopartikel $\mathrm{ZnO}$ komersial dengan konsentrasi nanopartikel dalam larutan pada proses padding sebesar $5 \%$. Penurunan kekuatan tarik pada studi sebelumnya ternyata lebih rendah, menggambarkan performa absorpsi UV yang lebih baik dibandingkan dengan hasil penelitian saat ini. Hasil ini dapat dipengaruhi oleh beberapa hal diantaranya yaitu konsentrasi nanopartikel $\mathrm{ZnO}$ pada larutan padding. Konsentrasi nanopartikel $\mathrm{ZnO}$ pada larutan padding dalam sintesis percobaan ini adalah sebesar 0,5\%, atau sekitar $10 \%$ dari konsentrasi yang digunakan pada studi terdahulu. Hal ini sejalan dengan kecenderungan umumnya bahwa performa absorpsi UV berbanding lurus dengan konsentrasi absorber UV yang digunakan. ${ }^{13}$

Selain konsentrasi absorber UV pada larutan, sistem immobilisasi adalah faktor yang turut mempengaruhi performa absorpsi UV. Sistem immobilisasi dengan menggunakan binder dan nanopartikel komersial secara praktikal akan lebih sederhana, dengan kemampuan perlekatan yang sangat baik. Namun keberadaan binder umumnya menyebabkan kain menjadi lebih tebal dan kaku, sehingga dalam beberapa aplikasi menjadi kurang sesuai. Sistem immobilisasi nanopartikel hasil sintesis laboratorium pada kain dengan proses kationisasi partikel dapat menghasilkan hasil proses kain yang lebih tidak kaku. Namun dalam sistem ini, jumlah nanopartikel yang melekat sangat bergantung reaksi kimia yang terjadi pada permukaan kain, sehingga perlu desain stoikiometri proses yang baik. Meski demikian, studi ini menunjukkan bahwa perlekatan nanopartikel terkationisasi pada kain cukup baik berdasarkan evaluasi performa absorpsi setelah setelah uji siram hujan yang tidak menunjukkan perubahan signifikan.

Salah satu kendala aplikasi absorber UV anorganik nanopartikel adalah terjadinya aglomerasi sehingga mengurangi efektivitasnya. Aglomerasi juga ditemukan pada studi ini, namun dari citra SEM terlihat bahwa nanopartikel ZnO hasil sintesis mampu meminimalisasi aglomerasi dibandingkan dengan immobilisasi nanopartikel $\mathrm{ZnO}$ komersial pada studi sebelumnya. ${ }^{12}$ Beberapa referensi menyebutkan nanopartikel $\mathrm{ZnO}$ komersial umumnya bermasalah pada aglomerasi yang dapat menyebabkan kesulitan dispersi uniform nanopartikel pada media finishing dan penurunan durabilitas. ${ }^{1,15}$ Dibanding senyawa oksida lain, nanopartikel ZnO memiliki distribusi ukuran partikel yang lebih sempit (20-40 nm) dan agregasi minimal sehingga memungkinkan distribusi uniform yang menghasilkan tingkat proteksi UV yang lebih baik. ${ }^{15}$

Secara umum, hasil penelitian ini tetap menunjukkan kontribusi dari immobilisasi absorber UV nanopartikel ZnO untuk memproteksi pengaruh negatif radiasi UV terhadap perubahan sifat fisik kain kapas. Penurunan sifat fisik pada berbagai jenis kain akibat pemaparan radiasi UV telah banyak dilaporkan pada studi lain, sekaligus mengindikasikan pentingnya penambahan absorber UV untuk proteksi material. ${ }^{9}$ Khususnya pada kain tenun kapas, porositas optik dan rasio volume permukaan yang tinggi memungkinkan penetrasi radiasi UV yang intensif, menyebabkan fotooksidasi dan menyebabkan berkurangnya elastisitas, kekuatan tarik dan peningkatan derajat kristalinitas. ${ }^{1}$ Mekanisme nanopartikel $\mathrm{ZnO}$ dalam mengabsorpsi UV secara umum mengikuti mekanisme tipikal absorber UV anorganik yaitu reduksi intensitas UV, atenuasi UV dan penyebaran sinar UV. ${ }^{16,17}$ Proses eksitasi elektron dari pita valensi ke pita konduksi dan absorpsi band gap merupakan mekanisme utama yang mempengaruhi reduksi intensitas dan atenuasi radiasi UV. Efektifnya nanopartikel ZnO sebagai absorber UV dipengaruhi oleh luas permukaan spesifik dan aktivitas permukaan yang besar, serta spektrum absorpsi UV yang lebar, sementara tipikal absorber UV anorganik lain memiliki puncak absorpsi hanya pada panjang gelombang tertentu. ${ }^{\mathbf{1 8 , 1 9 , 2 0}}$

\section{KESIMPULAN}

Dalam penelitian ini telah berhasil dilakukan sintesis nanopartikel $\mathrm{ZnO}$ dan dapat diimmobilisasikan pada kain kapas dengan menggunakan kationisasi partikel dengan trietilamin (TEA). Kationisasi dengan TEA 5\% cukup efektif dalam menimbulkan ikatan antara nanopartikel $\mathrm{ZnO}$ dengan serat kain. Perlekatan nanopartikel $\mathrm{ZnO}$ pada kain kapas tampak cukup baik setelah melalui uji siram hujan. Immobilisasi nanopartikel $\mathrm{ZnO}$ sebagai absorber UV yang diperoleh dari sintesis laboratorium memperlihatkan performa absorpsi UV yang baik, mampu meningkatkan ketahanan kain terhadap penurunan kekuatan tarik sampel kain kapas terhadap irradiasi UV selama 10 jam.

\section{UCAPAN TERIMAKASIH}

Penelitian ini terlaksana dengan bantuan anggaran penelitian DIPA Balai Besar Tekstil tahun 2016. 


\section{PUSTAKA}

1. Kim, Y.K. Ultraviolet protection finishes for textiles. Functional finishes for textile. $1^{\text {st }}$ ed. Elsevier (2015).

2. WHO, Solar ultraviolet radiation: global burden of disease from solar ultraviolet radiation, Environmental burden of disease series 13 (2006)

3. Dutra, E.A., Oliveira, D.A., Hackmann, E.R., \& Santoro. M.I. Determination of sun protection factor (SPF) of sunscreens by ultraviolet spectrophotometry. Brazilian Journal of Pharmaceutical Sciences 40 (3), 381 - 385 (2004).

4. Selishchev, D.S., Karaseva, I.P., Uvaev, V.V. Kozlov, D.V., \& Parmon, V.N. Effect of preparation method of functionalized textile materials on their photocatalytic activity and stability under UV irradiation. Chemical Engineering Journal 224, 114-120 (2013).

5. Radetic, M. Review: Functionalization of textile materials with $\mathrm{TiO}_{2}$ nanoparticles. Journal of Photochemistry and Photobiology C: Photochemistry Reviews 16, 62- 76 (2013).

6. Fakin, D., Veronovski, N., Ojstrsek, A., Bozic, M. Synthesis of $\mathrm{TiO}_{2}-\mathrm{SiO}_{2}$ colloid and its performance in reactive dyeing of cotton fabrics. Carbohydrate Polymers 88, 992- 1001. (2012).

7. Zayat, M., Garcia-Parejo, P. \& Levy, D. Preventing UV-light damage on light sensitive materials using a highly protective UVabsorbing coating, Chemical Society Reviews 36, 1270 - 1281 (2007).

8. Lu, Z., Mao, C., Meng, M., Liu, S., Tian, Y., $\mathrm{Yu}, \mathrm{L}$., et al. Fabrication of $\mathrm{CeO}_{2}$ Nanoparticlemodified Silk for UV Protection and Antibacterial Applications. Journal Colloid Interface Science 435, 8-14 (2014).

9. Li, H., Deng H. \& Zhao, J. Performance research of polyester fabric treated by nano titanium dioxide (nano- $\mathrm{TiO}_{2}$ ) anti-ultraviolet finishing. International Journal of Chemistry 1(1), 57 - 62 (2009).

10. Dastjerdi, R., Montazera, M., \& Shahsavan, S. A novel technique for producing durable multifunctional textiles using nanocomposite coating. Colloids and Surfaces B: Biointerfaces 81, 32-41 (2010).
11. Ibrahim, N.A., El-Zairy, E.M.R., Abdalla, W.A., \& Khalil, H.M. Combined UVprotecting and reactive printing of Cellulosic/wool blends, Carbohydrate Polymers 92, 1386- 1394 (2013).

12. Sugiyana, D., Septiani, W. Mulyawan, A.S., \& Wahyudi, T., Immobilisasi nanopartikel ZnO pada kain atap kapas dan evaluasi ketahanannya terhadap ultraviolet. Arena Tekstil 32 (1), 25-34 (2017).

13. El-Hady, M.M., Farouk, A. \& Sharaf, S. Flame retardancy and UV protection of cotton based fabrics using nano $\mathrm{ZnO}$ and polycarboxylic acids, Carbohydrate Polymers 92, 400- 406 (2013).

14. Wu, D. \& Long, M. Low-temperature synthesis of $\mathrm{N}-\mathrm{TiO}_{2}$ sol and characterization of $\mathrm{N}-\mathrm{TiO}_{2}$ coating on cotton fabrics, Journal of Colloid and Interface Science 358, 307-315 (2011).

15. Tsuzuki, T. \& Wang, X. Nanoparticle coatings for UV protective textiles, RJTA, 14 (2), 9 - 21 (2010).

16. Saravanan, D. Ultraviolet protection textile materials. AUTEX Research Journal 7 (1), 53 62 (2007).

17. Kasap, S.O. Electronic materials and Devices (3rd ed.), McGraw-Hill New York (2006).

18. Scalia, S., Tursilli, R., Bianchi, A., Lo-Nostro, P., Bocci, E., Ridi, F., et al. Incorporation of the sunscreen agent, octyl methocycinnamate in a cellulosic fabric grafted with bcyclodextrin. International Journal of Pharmaceutics 308, 155-159 (2006).

19. Mahltig, B., Böttcher, H., Rauch, K., Dieckmann, U., Nitsche, R. \& Fritz, T. Optimized UV protecting coatings by combination of organic and inorganic UV absorbers, Thin Solid Films 485 (1-2), 108-114 (2005).

20. Innes, B., Tsuzuki, T., Dawkins, H., Dunlop, J., Trotter, G., Nearn, M.R., et al. Nanotechnology and the cosmetic chemist. Cosmetics, aerosols and toiletries in Australia, 15 (10-12), 21-24. (2002). 
Arena Tekstil Vol. 32 No. 2, 2017: 59-66 